\title{
From what Makes Students Dislike Mathematics towards its Effective Teaching Practices
}

\author{
Do que faz com que os alunos não gostem da matemática em direção às \\ práticas de ensino eficazes
}

Fidele Ukobizaba*

ORCID iD 0000-0003-1502-2395

Kizito Ndihokubwayo**

ORCID iD 0000-0002-2566-8045

Angel Mukuka****

ORCID iD 0000-0003-0292-1324

Jean Uwamahoro****

ORCID iD 0000-0002-1730-6685

\begin{abstract}
This paper presents the findings of a descriptive survey research that investigated what makes students dislike Mathematics and seeks potentially effective Mathematics teaching practices, to boost their interest. The study involved 94 participants, including 60 lower-level secondary school students and 34 Mathematics teachers from 5 schools in Karongi District, Western Province, Rwanda. Both students' and teachers' questionnaire responses were analyzed using descriptive statistics. We found that what makes students dislike Mathematics is related to how Mathematics is taught. Low scores in tests or exams, teachers' harshness, and carelessness were reported among the factors demotivating students to like Mathematics. Being able to show the relevance of Mathematics in an everyday situation, teaching students to remember mathematical facts, and showing them lots of worked examples were mentioned by most of the teachers as indicators of effective Mathematics teaching practices. Together with these indicators, preparing the lesson before teaching, providing exercises and homework to students, and making research to update teachers' teaching skills have been drawn and recommended for teachers as potentially effective teaching practices.
\end{abstract}

Keywords: Attitude towards Mathematics. effective Mathematics teaching practices. Mathematics learning. Rwandan schools.

\footnotetext{
* BEd in Mathematics with Education from University of Rwanda - College of Education (UR-CE). Master Student at African Centre of Excellence for Innovative Teaching and Learning Mathematics and Science (ACEITLMS) University of Rwanda - College of Education (UR-CE), Kigali, Rwanda. E-mail: ukobifidele@gmail.com.

** Master of Education from the Graduate school for International Development and Cooperation (IDEC), Hiroshima University, Japan. Ph.D. Student at African Centre of Excellence for Innovative Teaching and Learning Mathematics and Science (ACEITLMS) University of Rwanda - College of Education (UR-CE), Hiroshima, Japan. E-mail: ndihokubwayokizito@gmail.com.

*** MSc in Mathematics Education from Copperbelt University, Zambia. Ph.D. Student at African Centre of Excellence for Innovative Teaching and Learning Mathematics and Science (ACEITLMS), University of Rwanda - College of Education (UR-CE), Kitwe, Zambia. E-mail: mukukaangel@ yahoo.com.

**** $\mathrm{PhD}$ in Space Physics from Rhodes University, South Africa. Deputy Director at African Centre of Excellence for Innovative Teaching and Learning Mathematics and Science (ACEITLMS) and Associate Professor of Physics at University of Rwanda - College of Education (UR-CE), Kigali, Rwanda. E-mail: mahorjpacis@ gmail.com.
} 


\section{Resumo}

Este artigo apresenta os resultados de uma pesquisa descritiva, que investigou o que faz os alunos não gostarem da Matemática, e buscou práticas de ensino da Matemática potencialmente eficazes para aumentar seu interesse. O estudo envolveu 94 participantes, incluindo sessenta alunos do ensino médio e 34 professores de matemática de cinco escolas, no distrito de Karongi, província ocidental, em Ruanda. As respostas dos alunos e professores aos questionários foram analisadas por meio de estatística descritiva. Descobrimos que o que faz os alunos não gostarem da matemática está relacionado à forma como a matemática é ensinada. Baixas pontuações em testes ou exames, a dureza dos professores e o descuido foram contados entre os fatores que desmotivam os alunos com a matemática. Ser capaz de mostrar a relevância da Matemática em uma situação cotidiana, ensinar os alunos a se lembrarem de fatos matemáticos e mostrar-lhes muitos exemplos trabalhados foram citados pela maioria dos professores como indicadores de práticas eficazes de ensino da Matemática. Junto com esses indicadores, preparar a aula antes de ensinar, fornecer exercícios e lição de casa aos alunos e fazer pesquisas para atualizar as habilidades de ensino dos professores foram ações citadas e recomendadas, para os professores, como práticas de ensino potencialmente eficazes.

Palavras-chave: Atitude em relação à matemática. práticas eficazes de ensino da matemática. aprendizagem da matemática. escolas ruandesas.

\section{Introduction}

Negative attitudes towards Mathematics, commonly known as 'math anxiety, are a serious problem to students at all educational levels today (GEIST, 2008). In its nature, teaching is a complex task that requires teachers to have support to change their teaching practices (SWAN, 2004). "There is a common belief that most students dislike Mathematics, due to an array of factors related to instruction and students' cognitive, affective and psychomotor attributes, subject matter, and the learning environment" (GAFOOR; KURUKKAN, 2015, p. 2). For instance, Ukobizaba, Ndihokubwayo, Uworwabayeho (2020) argued that teachers' mastery of the content and its effective delivery is not sufficient, but also showing care to students are among the factors that enhance students' interest in learning Mathematics.

"Creating a country of 'mathophobes' does not bode well for us in the uncertain global economy of the future" (GEIST, 2008, p. 29). That is why Rwanda's educational philosophy is that every citizen requires the knowledge that can help one adapt to society, and hence become a free competitive individual to the employment opportunities (RWANDA EDUCATION BOARD, 2015). However, the limited numbers of mathematically proficient students entering the workforce each year are insufficient to meet the desired outcomes. As a matter of urgency, there has been a severe need for the education sector to improve Mathematics learning outcomes. It could be one of the many reasons that led to the formulation and implementation of the Competence-Based Curriculum (CBC) in Rwanda (NDIHOKUBWAYO; HABIYAREMYE, 2018). The CBC has been preferred over the former one (Knowledge-Based Curriculum) due to its coverage of useful materials that are practical to teachers' needs and 
interests, well organized, and timed.

The current Mathematics syllabus in use helps students interact with teachers and try to use the knowledge gained by applying it in their daily life experiences and hence, being able to discover the importance of Mathematics (RWANDA EDUCATION BOARD, 2015). Moreover, Mathematics plays a significant role in society by enhancing students' thinking critically, logically, and abstractly. Research also shows that approaches such as group work and peer learning are not effectively applied in some Rwandan secondary schools (UKOBIZABA et al., 2019) to enhance the critical thinking, problem-solving skills, and creativity of students. It may slow down the significant role that Mathematics plays in society - enhancing the students' critical, logical, and abstract thought (TUCK-CHOY; TREAGUST, 2011).

Policymakers worldwide are calling schools and respective teachers to use effective research-based teaching practices (ANTHONY; WALSHAW, 2009) because teachers' teaching practices in the classroom are essential in changing students' attitudes towards Mathematics (AKINSOLA; OLOWOJAIYE, 2008). For instance, Hemmi and Ryve (2014) explored the effective teaching practices in Sweden and Finland. The results analysis from the interview and data from the feedback conversation revealed a reform movement that is apparent in terms of teaching practices in both countries. Teachers explained that effective teaching practices refer to interacting with students, building on their ideas, and trying to link the teaching process with students' everyday situation, while the Finnish teachers focused on a clear presentation of Mathematics, giving homework, and having a well-defined goal for each lesson.

As it has been confirmed by Schoenfeld (1989), students' motivation seems to spring from the right reasons. For instance, they claimed that the subject matter is enjoyable, learning the discipline helps them think clearly, and they wish to do well academically. However, they claim not to be motivated by their teachers, have a fear of looking stupid or getting into trouble during Mathematics classes. While investigating what influences the students' perceptions of Mathematics achievements, Mutodi (2014) revealed that five of the seven factors were crucial factors for students' performance in learning Mathematics. These factors are a lack of interest in Mathematics, weaknesses in Mathematics, family background and support, teacher support and learning materials, beliefs about Mathematics, self-confidence, difficulties in doing Mathematics, and myths.

Counting from thirty years back onwards, Mathematics educators and mathematicians become aware of the effects of students' attitudes towards Mathematics. Students attitudes towards Mathematics influence on what students learn either in class or out of the classroom (ROYSTER; HARRIS; SCHOEPS, 1999). During the investigation related to the influence of 
learning and students' performance in Mathematics in secondary schools, the findings revealed that the crucial problem connected to the attitudes is the lack of confidence, ability, and interest to learn and do Mathematics for secondary school students. However, $56 \%$ of the asked students strongly agreed that they like learning Mathematics, and most of them would like to continue doing Mathematics after secondary education because they believe that Mathematics is essential in their daily life (MUTAI, 2010). Furthermore, the study conducted in Nigeria (BALA; HYELNIS; UMAR, 2016) declared that students' success is highly determined by the teacher's qualifications, teaching methods, and the instructional materials used while teaching.

Diagnosing negative attitudes towards Mathematics has been incontrollable for teachers. It is necessary to explore and point out the students' construct attitudes while thinking about effective practices that motivate students to make this diagnosis (DI; ROSETTA, 2010). For instance, Tuck-Choy and Treagust (2011), conducted a study with emphasis on exploring students' issues related to students' difficulties, misconceptions, and attitudes towards algebra. Learning Mathematics in a free environment (SANCHAL; SASHI, 2017) raises students' attitudes, self-reported questionnaires, self-engagement, awareness, and confidence. However, there is a worry that elementary and high school students may avoid learning Mathematics and prefer to take less Mathematics classes because of negative attitudes towards the subject, which may also prevent them from pursuing higher learning (GEIST, 2008). Nevertheless, as it was in the past times and today, students are still struggling with Mathematics and this struggle affects their engagement. To find a solution to this issue, we must understand how effective teaching looks like (ANTHONY; WALSHAW, 2009). Therefore, there is a need for teachers to understand what are effective teaching practices that will enhance students' engagement in constructing their interest, creativity, application, and discovery (MISTIMA; MAAT, 2010). Besides, enabling teachers to learn and reflect on their teaching practices implications is a promising way to improving instructions that will accommodate all students at all levels (STIGLER; HIEBERT, 2004). The present study intends to investigate what makes students dislike learning Mathematics and proposes the potential effective teaching practices that enhance students' interest in Mathematics.

The present study was guided by the cognitivism theory initiated by Edward Chace Tolman in 1920 and adopted as a learning theory in the early Twentieth Century (YILMAZ, 2011). Yilmaz explains the cognitivism theory as a process of illuminating how learning occurs in different contexts by using different teaching strategies that enhance both teachers and students to access an effective teaching and learning environment. The present study was also guided by one of the motivational theories, commonly known as self-determination theory 
(SDT). Deci and Ryan (2012) explain SDT as an empirically derived theory of human motivation and personality that differentiates motivation from being autonomous and controlled. It is predicted that if Mathematics teachers use effective teaching practices, students will, in turn, like Mathematics.

Integrating the curriculum documentation for teachers is still a vague idea in Mathematics teaching and learning, whereby some teachers cannot manipulate the curriculum (UMUGIRANEZA; BANSILAL; NORTH, 2018). Rwandan teachers claimed some issues related to the curriculum (NDIHOKUBWAYO; HABIYAREMYE, 2018). These issues included (a) contents that are too heavy for students' level, (b) many exercises that do not allow them to link the content with a real-life situation, (c) activities that are not practical and engaging activities with the aspect of developing competences, and (d) many materials to deal with which do not match with the time given to finish it. Consequently, teachers move on with those students who are talented and able to follow them (HANDAL, 2003). The remaining part of the students feels lost and demotivated, which results in trying to dodge the Mathematics teaching periods for some students. What is commonly known is that the faculty 'teaches the way they were taught'. Little is known about the role played by the faculty's prior teaching experience to develop their teaching practices (OLESON; HORA, 2013). The efforts of many are required to adopt principles of classroom pedagogical teaching practices for a significant improvement of students' interest towards improved learning outcomes. These adoptions are expected to be discussed within the classroom, in Mathematics teams, departments, or faculties, and in teacher education programs (ANTHONY; WALSHAW, 2009). Thus, the support to deal with this issue is needed to see how this can be remediated.

The standards in Mathematics achievements in sub-Saharan Africa (SSA) nations are shallow (BETHELL, 2016). Although people argue that many students are failing in today's Mathematics education still, there is a disagreement about how this problem can be solved (HAGLUND, 2004). In East African countries where Rwanda is included, students' pass rate and average scores in Mathematics are still low (HALAI; TENNANT, 2014). Likewise, students in Rwanda are considering Mathematics as a difficult subject (UKOBIZABA et al., 2019) and therefore lose interest in undertaking it, and therefore perform poorly. Low performance declines the number of students who may prefer to learn Mathematics (POPOOLA; OLAREWAJU, 2010). Besides, this impacts many students who join vocational and technical education courses because they do not have sufficient mathematical skills for today's needed abilities to perform jobs successfully at the workplace (STONE; ALFELD; PEARSON, 2008). In response to such a timely call and based on the problem highlighted 
above, the present study sought to explore the potential teaching practices of Mathematics that can enhance students' positive attitudes and motivation to learn Mathematics and the potential ways this subject can be taught effectively. More specifically, the present study intends to answer the following research questions:

i. What are the potential reasons why students dislike learning Mathematics?

ii. What are the Mathematics teachers' beliefs about what they consider as effective teaching practices of Mathematics that enhance students' interest?

\section{Research Methodology}

To collect data, six schools from Karongi District, Western Province, Rwanda, were inconveniently sampled, targeting ordinary level students (grade 7 to grade 9) as the present study population. Thus, 60 students ( 31 male and 29 female) were randomly selected and participated in the study. The students' average age was 15 years old. Besides, 34 Mathematics teachers (22 male and 12 female) were purposively selected to participate in the study. Teachers' teaching experience was ranging from one to 40 years.

To answer the research questions, the present study employed a descriptive survey design. This design was deemed appropriate for its leading role in providing insights into how people interact with the environment in real situations (COHEN; MANION; MORRISON, 2007). The questionnaires were constructed by researchers themselves based on the research questions. The students' questionnaire items were grouped into two main themes; (i) what makes students dislike Mathematics (6 items), and (ii) students' algebraic expressions' performance (4 items). Six items were considered enough by researchers to provide an insight into why students dislike Mathematics. In addition, four algebraic expressions were used to explore students' challenges in algebra that can make them dislike Mathematics to answer the first research question. Algebra was considered because it is mostly abstract and affects students' attitudes towards Mathematics (GEIST, 2008).

The teachers' questionnaire was constructed to provide answers to the second research question. Its constructs were grouped into two main themes; (i) teachers' perception about a good teacher (4 items), and (ii) teachers' teaching practices of Mathematics (4 items). Questionnaires were administered in English to both students and teachers. We used 4-types Likert-scales ranging from 1 (strongly agree) to 4 (strongly disagree) as well as from 1 (never) to 4 (often). The Kuder-Richardson approach was used to calculate the internal consistency of the questionnaire. The calculated reliability estimate for the students' questionnaire was .93, 
while for the teachers was .71. The questionnaires were found valid after being checked by experts from the University of Rwanda College of Education, who evaluated their construct against the research questions.

Before the collection of data, the school authorities were informed by the researchers. Arriving at school, the researcher - first author, handed over the letter requesting authorization to collect data. After receiving the letter, the school leaders (headteacher or director of studies) facilitated the data collection activity by introducing the researcher to the teachers and students. The data collection immediately started as students were found in their classroom setting. Before distributing and filling the questionnaire, students and teachers learned the aim of the study. Teachers and students were assured that their personal identifications and the information provided would be kept anonymously and only used for the study's purposes. Both students and teachers signed a consent form, accepting to participate in the study voluntarily. All questionnaires were filled by the respondents and returned.

\section{Data Analysis and Presentation}

Data were analyzed using Microsoft Excel 2016. Descriptive statistics were computed and presented in tables. Since we intended to collect categorical data, each item was represented in frequencies and percentages, showing the respondents' frequency with each statement. Further, in the results and discussion section, we summed up the two wings of the scale. Thus, we put together the percentage of strongly agree and agree, and we put together the percentage of disagree and strongly disagree. The positive wing was titled "agree" while the negative wing was titled "disagree." Similarly, "used" was the sum of sometimes and often while "not used" was the sum of never and seldom.

\subsection{Students' Reasons for Disliking Mathematics}

Table 1 shows the frequencies of items describing what make students dislike Mathematics. The numbers presented in Table 1 reflect the proportion (\%) of students for each level of agreement to the suggested reasons to dislike Mathematics, where $1=$ strongly disagree, 2 = disagree, $3=$ agree, and $4=$ strongly agree. $\mathrm{N}$ is the total number of students who responded to each item. 
Table 1 - What makes students dislike Mathematics

\begin{tabular}{cccccc}
\hline $\begin{array}{c}\text { Suggested Reasons to Dislike } \\
\text { Mathematics }\end{array}$ & $\mathbf{N}$ & $\mathbf{4}$ & $\mathbf{3}$ & $\mathbf{2}$ & $\mathbf{1}$ \\
\hline $\begin{array}{c}\text { Getting low grades in math tests and } \\
\text { exams }\end{array}$ & 60 & 45 & 25 & 21.7 & 8.3 \\
\hline $\begin{array}{c}\text { Teacher being harsh and careless } \\
\text { Teacher giving unclear examples }\end{array}$ & 58 & 25.9 & 24.1 & 20.7 & 29.3 \\
\hline $\begin{array}{c}\text { Failure to see the value of Mathematics } \\
\text { in daily life }\end{array}$ & 60 & 16.7 & 30 & 33.3 & 22 \\
\hline $\begin{array}{c}\text { Teacher's regular use of group work } \\
\text { Too many exercises given by the teacher }\end{array}$ & 54 & 13 & 22.2 & 26 & 38.8 \\
\hline
\end{tabular}

Source: Prepared by the authors

\subsection{Students' ability and confidence to solve algebraic expressions}

Table 2 shows the students' performance on algebraic expression. The bold numbers correspond to correct answers. $\mathrm{N}$ is the total number of students who attempted each question item while the percentage of students who answered a certain letter to each of four items is presented under each letter (A, B, C, or D)

Table 2 - Students algebraic expressions' performance

\begin{tabular}{|c|c|c|c|c|c|c|}
\hline & Choose the correct answer & $\mathrm{N}$ & A & $\mathrm{B}$ & $\mathrm{C}$ & $\mathrm{D}$ \\
\hline \multirow[t]{2}{*}{1} & $x+10=0 x$ equals to: & 59 & 10.2 & 16.9 & 8.5 & 64.4 \\
\hline & C) 100 & & & & & \\
\hline 2 & 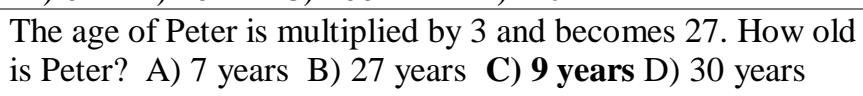 & 58 & 3.4 & 8.6 & 77.6 & 10.3 \\
\hline \multirow[t]{2}{*}{3} & Simplify $\frac{2^{5}}{2^{3}}=?$ & 60 & 5.0 & 5.0 & 38.3 & 51.7 \\
\hline & A) $2^{5} \quad$ B) $2^{3}$ & & & & & \\
\hline \multirow[t]{2}{*}{4} & $\begin{array}{l}\text { Complete with the missing factor into brackets } \\
10 m^{5}=(-5 m)(?)\end{array}$ & 58 & 15.5 & 60.3 & 19.0 & 5.2 \\
\hline & $\begin{array}{llll}\text { A) } 2 m & \text { B) }-2 m^{5} & \text { C) }-2 m^{4} & \text { D) } 2 m^{4}\end{array}$ & & & & & \\
\hline
\end{tabular}

Source: Prepared by the authors

\subsection{Teachers' Views about Effective Mathematics Teaching Practices}

Before revealing effective ways in which Mathematics should be taught, teachers were requested to rate their capacity for teaching Mathematics from very low to very high. Results showed that $59 \%$ and $21 \%$ rated high and very high, respectively. Additionally, their confidence in teaching Mathematics was rated high and very high by $56 \%$ and $35 \%$ of the teachers, respectively. Furthermore, when asked the time when teachers arrive at school, most of them responded they arrive early at school every day and some days (82\% arrive early every day, while $18 \%$ arrive early on some days). Besides, teachers were also asked to indicate the extent to which they agree with the definition of a good teacher (see Table 3) as suggested indicators. 
Table 3 - Teachers' beliefs about a good Mathematics teacher

\begin{tabular}{cccccc}
\hline $\begin{array}{c}\text { Suggested Indicator of a good } \\
\text { Mathematics Teacher }\end{array}$ & $\mathbf{N}$ & $\mathbf{4}$ & $\mathbf{3}$ & $\mathbf{2}$ & $\mathbf{1}$ \\
\hline Being good at Mathematics & 34 & 32.4 & 64.7 & 2.9 & 0.0 \\
\hline $\begin{array}{c}\text { Being able to show Mathematics in an } \\
\text { everyday situation }\end{array}$ & 34 & 64.7 & 32.4 & 2.9 & 0.0 \\
\hline $\begin{array}{c}\text { Teaching students to remember } \\
\text { Mathematical facts }\end{array}$ & 34 & 55.9 & 44.1 & 0.0 & 0.0 \\
\hline Showing students lots of worked examples & 33 & 57.6 & 39.4 & 3.0 & 0.0 \\
\hline
\end{tabular}

Note. The numbers presented in Table 3 reflect the proportion (\%) of teachers for each level of agreement to the suggested indicators of a good Mathematics teacher where $1=$ strongly disagree, $2=$ disagree,

3 agree, and $4=$ strongly agree. $\mathrm{N}$ is the total number of students who responded to each item.

Source: Prepared by the authors

When we asked teachers whether students concentrate on their lessons while teaching, most of them (97\%) responded, “yes". The reasons for students' concentration, among others, were that their teachers used several methods and strategies such as putting students into group work and giving many exercises to students. However, the asked teachers revealed that some of the reasons that make students distracted and not concentrated are the lack of mathematical applications in real life and lacking or having insufficient prior knowledge. A follow-up statement was provided asking teachers to rate how often they practiced some of the teaching practices that were suggested as effective. Table 4 illustrates their ratings on the frequency with each of the suggested practices is implemented.

Table 4 - Teachers' teaching practices of Mathematics

\begin{tabular}{cccccc}
\hline Suggested Effective Teaching Practices & $\mathbf{N}$ & $\mathbf{4}$ & $\mathbf{3}$ & $\mathbf{2}$ & $\mathbf{1}$ \\
\hline Lesson preparation before teaching & 34 & 67.6 & 32.4 & 0.0 & 0.0 \\
\hline Giving homework to students & 34 & 73.5 & 26.5 & 0.0 & 0.0 \\
\hline Giving exercises to students & 34 & 88.2 & 11.8 & 0.0 & 0.0 \\
\hline Updates on effective teaching skills & 33 & 57.6 & 42.4 & 0.0 & 0.0
\end{tabular}

Note. The numbers presented in Table 1 reflect the proportion (\%) of teachers for each agreement level to the suggested effective teaching ways where $1=$ never, $2=$ seldom, $3=$ sometimes, and $4=$ often. $\mathrm{N}$ is the total number of students who responded to each item.

Source: Prepared by the authors

\section{Results and Discussion}

The results showed that low marks and harsh and careless teachers can demotivate students to learn Mathematics. Seventy and $50 \%$ of the students agreed on these two statements, respectively (Figure 1). However, many exercises, working in groups, were not found as factors motivating students to dislike Mathematics. Only 36.8\% and 35.2\% agreed that "too many exercises given by teacher" and the teacher's regular use of group work" make them dislike Mathematics, respectively. 


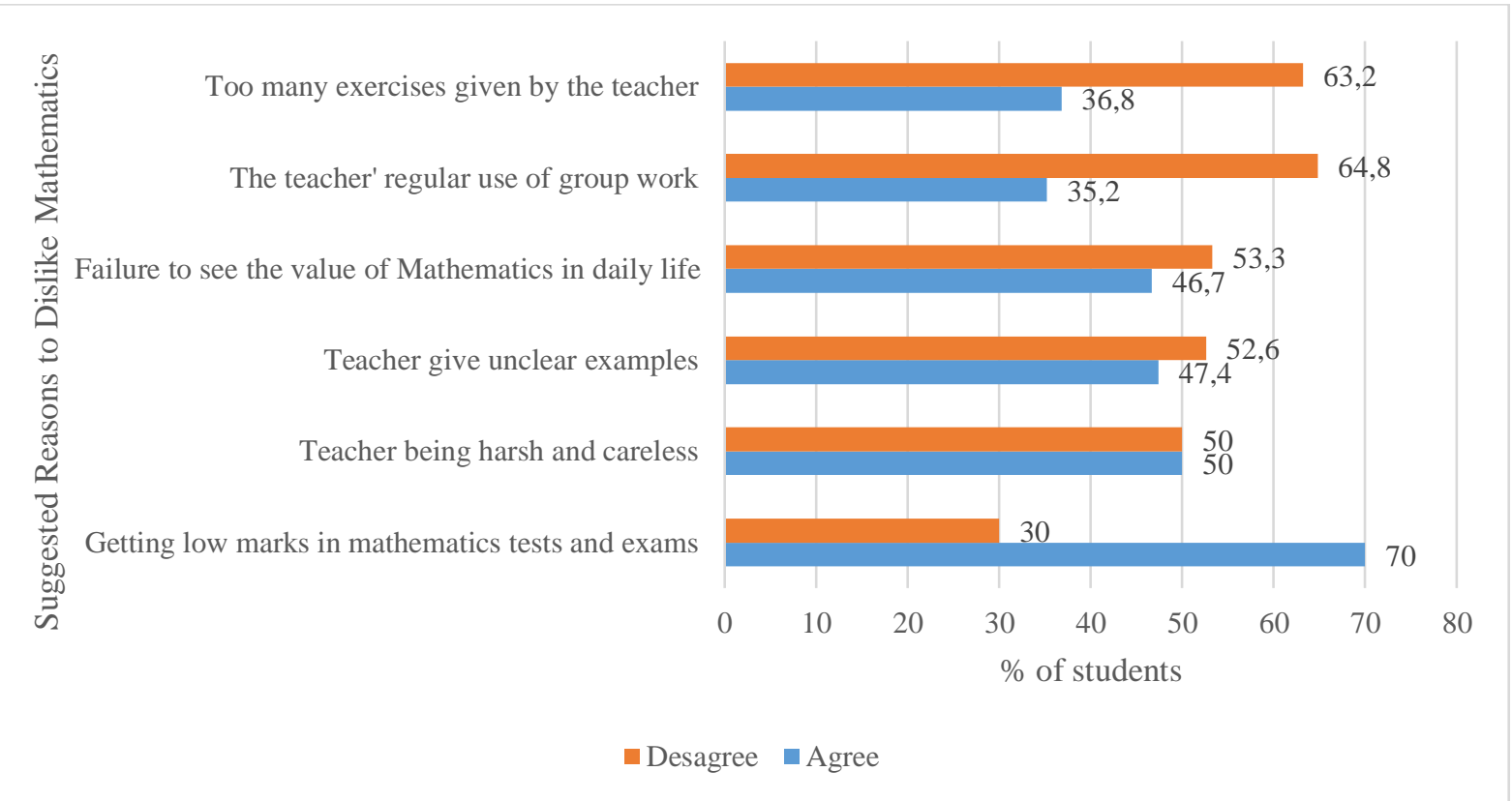

Figure 1 - Why students dislike Mathematics Source: Prepared by the authors

The fact that students disliked Mathematics because their teachers are harsh and careless reminds Mathematics teachers how they should behave in front of the students while interacting with them. As also stated by Ukobizaba et al. (2019), students appreciate teachers who are careful, approachable and value the students' needs and interests. Furthermore, an effective teacher is one who shows a kind of care in the classroom by assisting students to develop their mathematical skills and giving them a chance to express themselves independently, and allowing classmates discussions (ANTHONY; WALSHAW, 2009). A caring teacher, group work, and enough exercises were ranked topmost reasons why students like Mathematics. Of course, everyone needs care, so teachers always need to be kind enough to harmonize the teaching activities to the students' social lives. However, in the Mukuka et al. (2019) study, it was reported that cooperative learning such as group work traces fear on teachers as $64 \%$ of the respondents found resisting to this approach due to a large number of students, assessment time, and pressure to complete syllabus. The results analysis showed that most asked students (97\%) enjoy Mathematics when shown its relevance in everyday life. We, therefore, agree with Peck (2018), who argued that if students are guided and explained the relevance of studying Mathematics, this will likely help them to enjoy Mathematics and learn it with all their hearts. When you talk to most of the students, they tell you that they do not like teachers who give them many notes, tests, and exercises. However, within the present study, most students (63\%) disagreed that being given many exercises can make them dislike Mathematics.

Before suggesting the potential effective teaching practices in Rwandan secondary 
schools, we gave a short test to students to check their ability in algebraic expressions. From the students' capacity and confidence towards learning Mathematics, most of them can solve the questions when given algebraic expressions. However, students showed difficulties in multiplying expressions with powers. The percentage of $81 \%$ of students failed question 4 (other than answer C), while they succeeded in question 3 (answer D), with 51\% of students (Figure 2).

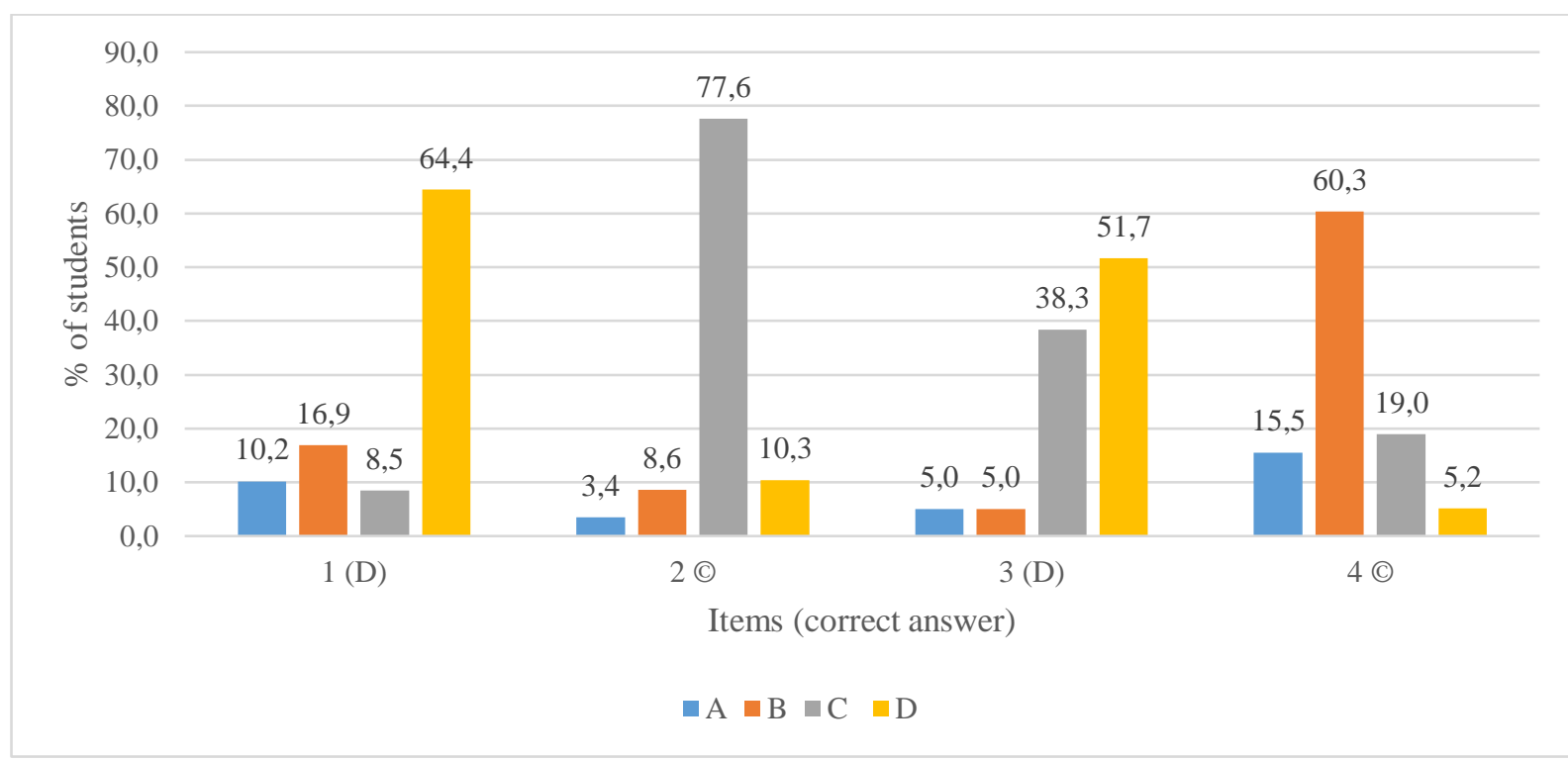

Figure 2 - Students' Algebraic expression performance Source: Prepared by the authors

All these questions have a similarity of the addition of powers (see Table 2), but to complete the missing factor into brackets (question 4) became more challenging than simplification (question 3). The reflections made on the potential causes of student errors led to the conclusion that the language used in some questions was not familiar to most students. For instance, the "missing factor" might not have been easily grasped by most students who are used to terms such as simplifying, factorizing, expanding, etc. These findings do not seem to be unique to Rwandan students only. Studies conducted in other contexts have also found related facts. Students' difficulties in understanding questions (ZAHARA; HOSSAIN, 2010), their difficulties in communicating mathematically, and their failure to multiply algebraic expressions involving powers (MUKUKA; BALIMUTTAJJO; MUTARUTINYA, 2020) were some of the issues that deserve the attention of teachers to improve the quality of learning school Mathematics.

All the students' responses regarding the reasons for disliking Mathematics pointed to issues related to teachers' instructional and assessment methods in their classrooms. It is well depicted in the theory of cognitivism (YILMAZ, 2011) and the theory of self-determination 
(DECI; RYAN, 2012) that students decide to fully engage in learning Mathematics depending on motivational instructions selected by their teachers. It has been clearly stated that students' interest, confidence, and performance in Mathematics can be improved when teachers employ effective teaching practices.

Students' failure in algebra ends with students' negative attitudes towards Mathematics (TUCK-CHOY; TREAGUST, 2011). Through the language of algebra, students can manipulate mathematical patterns, make analysis, solve problems, perform arithmetic operations, and make generalizations (SIEW; LEE, 2012). The study's results of Tuck-Choy and Treagust (2011) indicated that students' difficulties and misconceptions are generated from the low level of understanding letters and places in Mathematics, the ability to manipulate letters or variables, the rules used in manipulating those letters and variables, the ability to use their algebraic structure knowledge to form equations, and the ability to generalize for repetitive patterns. Additionally, Macgregor and Price (2002) found that some students' failure in algebra is linked to students' low skills in metalinguistic. The authors argued that the awareness of language structure and the ability to deal with those structures leads to an understanding of algebraic notations. In the research conducted using attitudinal questionnaires (BETHELL, 2016), with 52 teachers of primary teaching level and 18 teachers of secondary teaching level, about half of them filled the questionnaire claiming that they are fluent in the language of instruction. However, $40 \%$ of the teachers stated that they have difficulties in instruction language while teaching. Again, nearly all Mathematics teachers (87\%) suggest that more in-service assistance is needed to boost students' achievements in return.

When we asked teachers: "Are your students focused on your lesson while teaching Mathematics?" The majority of teachers (97\%) responded "yes". The common reasons revealed by some of the teachers (34\%) for the focus were that those students like Mathematics when they are provided with concrete examples, putting students in group discussion, giving homework, sharing funny stories throughout the instruction, showing the relevance of the lesson, and demonstrating confidence while introducing the lesson. Besides, the asked teachers came up with what demotivate their students and make them distracted. Some of the provided reasons by the majority of teachers $(60 \%)$ that make students being distracted are such as the students' lack of mathematical applications in real life, lack of or insufficient prior knowledge, which pushes students to be passive, and thus create some disturb in class. Rwandan teachers describe a good Mathematics teacher as one who teaches students to remember facts, is good at content, is able to show Mathematics in everyday life, and shows multiple worked examples to students (see Figure 3). 


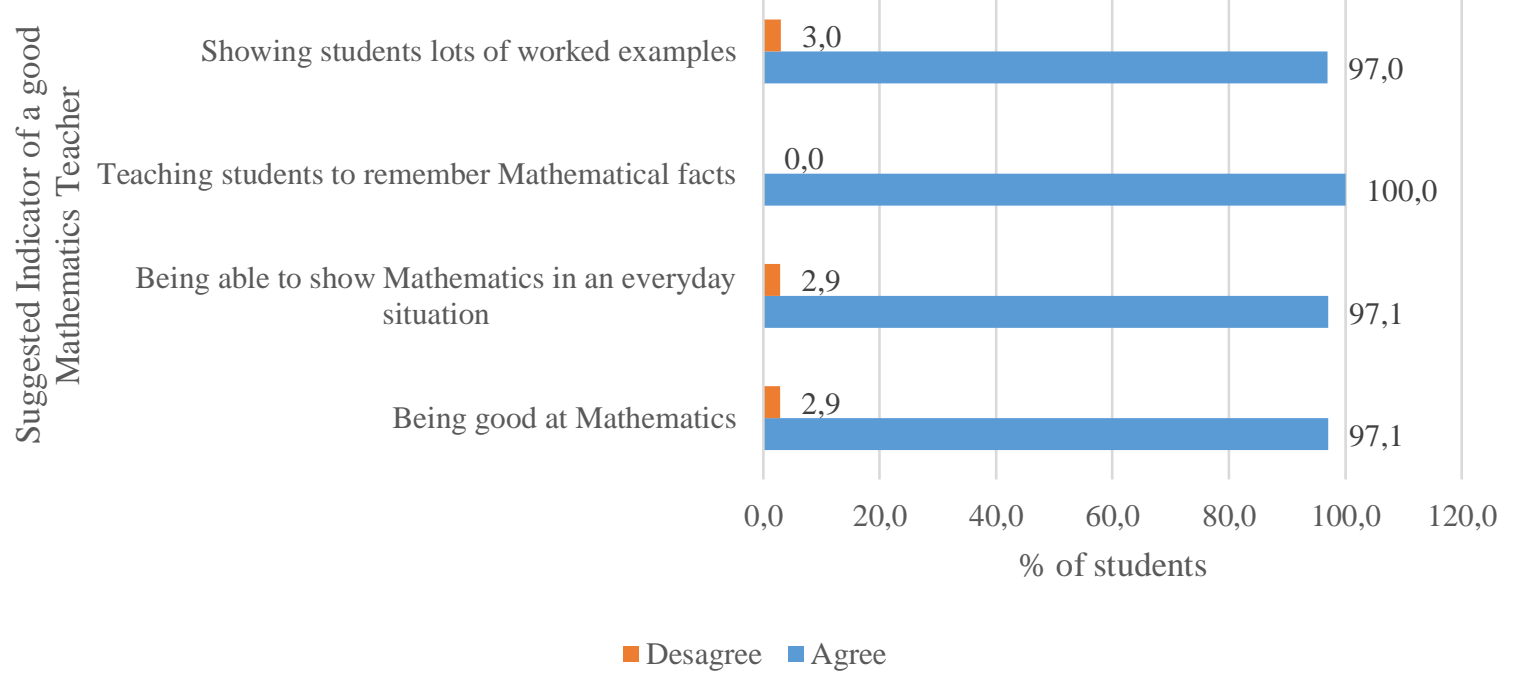

Figure 3 - A good Mathematics teacher Source: Prepared by the authors

Most teachers (97\%) have reported that a good teacher is one who is equipped with sufficient content that they master and are able to deliver it effectively. Likewise, teachers believe that mastering the content, being able to link Mathematics with an everyday situation, helping students to remember mathematical facts, and showing worked examples are the crucial factors that motivate students to learn Mathematics (HAGLUND, 2004; SCHWEINLE et al., 2006). Indeed, there is a significant relationship between teacher quality and students' success (GICHURU; ONGUS, 2016). Hence, teachers need to improve Mathematics knowledge for teaching primarily in pedagogical content (HABIYAREMYE, 2016). Since $52 \%$ and $48 \%$ of students started hating Mathematics when they were still in primary and secondary school, respectively, this showed that there is a need to make students love Mathematics at a very early age once they start learning Mathematics. It is confirmed by Haglund (2004), who suggested that the use of the humanistic approach, which is concerned with applying Mathematics at an early age, will help students boost their learning self-efficacy.

Results displayed in Figure 4 indicate that most of the teachers were often employing each of the suggested teaching practices. The overall impression is that an effective teacher is the one who prepares a lesson before teaching, gives exercises and homework to students, and regularly updates their mathematics content and pedagogical knowledge.. 


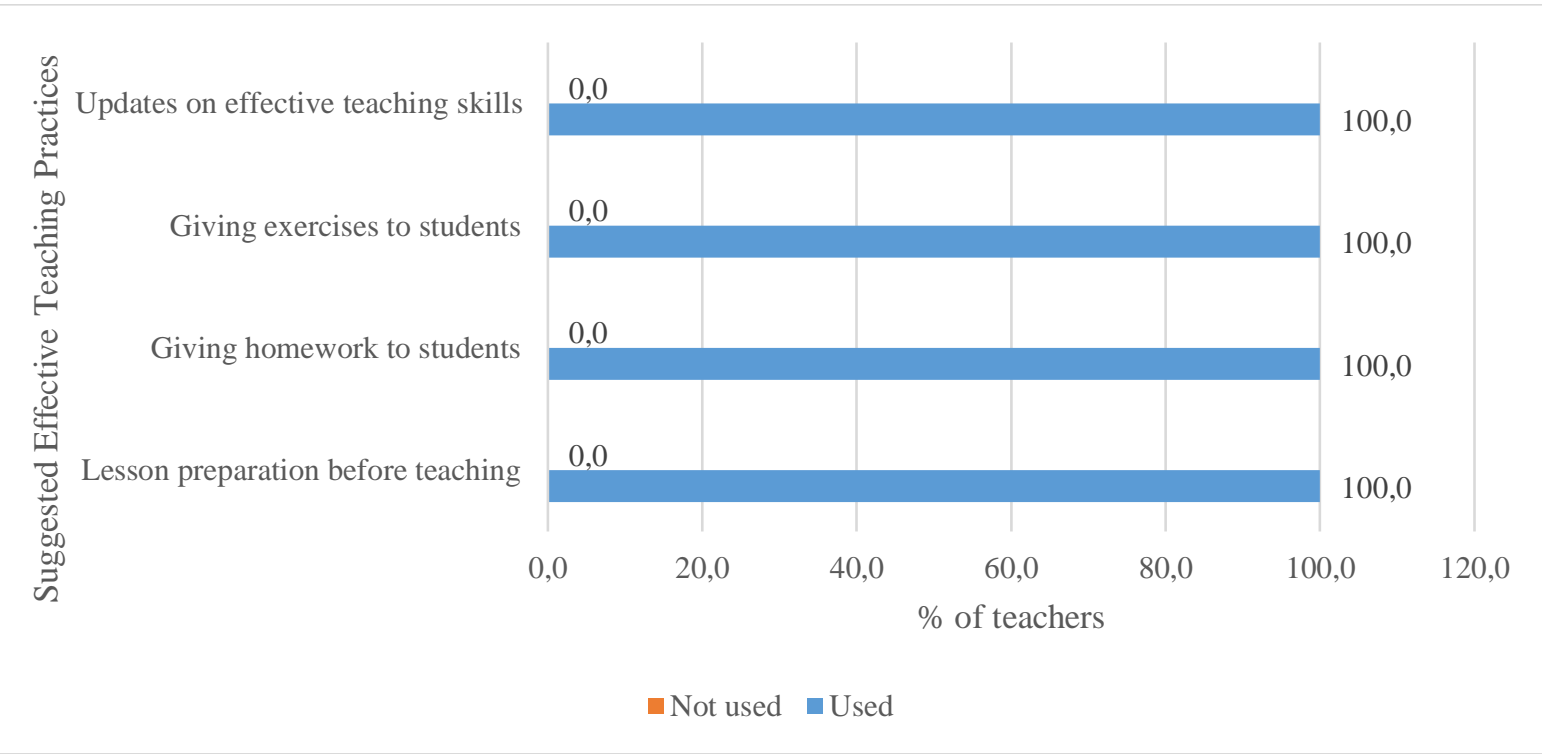

Figure 4 - Frequency of teaching practices

Source: Prepared by the authors

Based on suggestions from teachers and students, effective Mathematics teaching practices involves; (a) adequate preparation before lesson presentation, (b) teachers' clear explanations of mathematical concepts and enough examples, (c) administration of adequate homework, exercises, and tests, (d) effective implementation of group work, (e) teachers' showing a sense of humor to the diverse student needs, and (f) linking classroom Mathematics to real-life situations. Regular holding of Continuing Professional Development (CPDs) can help in orienting serving teachers of Mathematics in both primary and secondary schools and eventually improve Mathematics teaching and learning.

\section{Conclusions}

The reasons why students dislike Mathematics, and the potential ways to teach it were explored. Students dislike Mathematics because of getting low marks in tests and exams; however, they had no objection to being provided with a lot of exercises. The implications drawn from this study are that teachers need to link classroom Mathematics to real-life situations, prepare lessons adequately before the presentation, give clear explanations of mathematical concepts, use clear examples, administer adequate homework and exercises, provide tests with feedback provision, implement significant group works, and show a sense of humor while responding to the diverse students' needs. This study's limitation is that it has been conducted in one part of the country, intending to generalize the findings. Therefore, there is a call for further studies covering a large scale of the country for more generalization. 


\section{Acknowledgments}

The authors acknowledge the school authorities who allowed the data collection process; teachers and students who willingly participated in the study. Especially, we thank the administration at Ecole Secondaire Urumuli located in Karongi district that made this work successful.

\section{References}

AKINSOLA, M. K.; OLOWOJAIYE, F. B. Teacher Instructional Methods and Student Attitudes towards Mathematics. International Electronic Journal of Mathematics Education, Ankara, v. 3, n. 1, p. 60-73, 2008.

ANTHONY, G.; WALSHAW, M. Characteristics of effective teaching of mathematics: A view from the West. Journal of Mathematics Education, Southeast Sulawesi, v. 2, n. 2, p. 147-164, 2009.

BALA, D.; HYELNI, E.; UMAR, M. A. Students' Perception of Factors Influencing Teaching and Learning of Mathematics in Senior Secondary Schools in. Journal of Education and Practice, New York, v. 7, n. 20, p. 114-122, 2016. Available at: https://files.eric.ed.gov/fulltext/EJ1109160.pdf. Access in: 21. Nov. 2019

BETHELL, G. Mathematics Education in Sub-Saharan Africa: Status, Challenges, and Opportunities. Africa: [s.n.], 2016. Available at: https://elibrary.worldbank.org/doi/abs/10.1596/25289. Access in: 21. Nov. 2019.

COHEN, L.; MANION, L.; MORRISON, K. Research Methods in Education. 6. ed. New York: Routledge, 2007.

DECI, E. L.; RYAN, R. M. Self-determination theory. In: van LANGE, P. A. M.; KRUGLANSKI, A. W.; HIGGINS, E. T. (Eds.). Handbook of theories of social psychology. [S.1.]: Sage Publications Ltd, 2012. pp. 416-436.

DI, P.; ROSETTA, M. 'Me and maths': towards a definition of attitude grounded on students' narratives. Journal Mathematics Teacher Education, Stuttgart, v. 13, p. 27-48, 2010.

GAFOOR, K. A.; KURUKKAN, A. Why High School Students Feel Mathematics Difficult ? An Exploration of Affective Beliefs. [s. l.]: [s. n.], 2015.

GEIST, E. The Anti-Anxiety Curriculum : Combating Math Anxiety in the Classroom. Journal of Instructional Psychology, Phoenix, v. 37, n. 1, p. 24-31, 2008.

GICHURU, L. M.; ONGUS, R. W. Effect of teacher quality on student performance in mathematics in Primary 6 National Examination: A survey of private primary schools in Gasabo District, Kigali City, Rwanda. International Journal of Education and Research, Amsterdam, v. 4, n. 2, p. 237-259, 2016.

HABIYAREMYE, H. T. Analysis of Mathematical Knowledge for Teaching in Rwanda Secondary Schools Focus on Algebraic Equation Concepts. 2016. 140 f. Thesis (Master in Education) - Hiroshima University, Hiroshima, 2016.

HAGLUND, R. Using Humanistic Content and Teaching Methods to Motivate Students and 
Counteract Negative Perceptions of Mathematics. Humanistic Mathematics Network Journal, Calfonia, v. 1, n. 27, p. 1-18, 2004.

HALAI, A.; TENNANT, G. Mathematics Education in East Africa: Towards Harmonization and Enhancement of Quality Education. Dar es Alaam: Springer, 2014.

HANDAL, B. Teachers' mathematical beliefs: A review. The Mathematics Educator, Atlanta, v. 13, n. 2, p. 47-57, 2003.

HEMMI, K.; RYVE, A. Effective mathematics teaching in Finnish and Swedish teacher education discourses. New York: Springer, 2014.

MACGREGOR, M.; PRICE, E. An exploration of aspects of language prficiency and algebraic learning. Lessons Learned from Research, Melbourne, v. 200, p. 109-116, aug. 2002.

MISTIMA, S.; MAAT, B. An Exploration of Mathematics Teachers' Reflection on Their Teaching Practices. Asian Social Science, Ontario, v. 6, n. 5, p. 147-152, 2010.

MUKUKA, A.; BALIMUTTAJJO, S.; MUTARUTINYA, V. Exploring students' algebraic reasoning on quadratic equations: Implications for school-based assessment. Proceedings of the epiSTEME8 International Conference to Review Research in Science, Technology, and Mathematics Education. Mumbai. p. 130-138, 2020.

MUKUKA, A.; MUTARUTINYA, V.; BALIMUTTAJJO, S. Exploring the barriers to effective cooperative learning implementation in school mathematics classrooms. Problems of Education in the 21st Century, Siauliai, v. 77, n. 6, p. 745-757, 2019. Available at:

https://doi.org/10.33225/pec/19.77.745.

MUTAI, J. K. Attitudes towards Learning and Performance in Mathematics among Students in Selected Secondary Schools in Bureti District, Kenya. 2010. Thesis (Master in Education) Kenyatta University, Nairobi, 2010.

MUTODI, P.; NGIRANDE, H. The Influence of Students` Perceptions on Mathematics Performance. A Case of a Selected High School in South Africa. Mediterranean Journal of Social Sciences, London, v. 5, n. 3, p. 431-445, 2014.

NDIHOKUBWAYO, K.; HABIYAREMYE, H. T. Why did Rwanda shift from knowledge to competence-based curriculum? Syllabuses and textbooks point of view. African Research Review, Addis Ababa, v. 12, n. 3, p. 56-65, 2018.

OLESON, A.; HORA, M. T. Teaching the way they were taught? Revisiting the sources of teaching knowledge and the role of prior experience in shaping faculty teaching practices. High Education, Dordrecht, v. 68, p. 29-45, 2013.

PECK, F. A. Rejecting Platonism: Recovering Humanity in Mathematics Education. Education Sciences, Basel, v. 43, n. 8, p. 1-13, 2018.

POPOOLA, F. R.; OLAREWAJU, R. R. Factors responsible for poor performance of students in mathematics in Nigerian Secondary Schools. Journal of Research in Education and Society, Ankara, v. 1, n. 2, p. 55-65, 2010.

ROYSTER, D. C.; HARRIS, K. M.; SCHOEPS, N. Dispositions of college mathematics students. International Journal of Mathematics Education, Science and Technology, Ankara, v. 30, n. 3, p. 317-333, 1999.

RWANDA EDUCATION BOARD. Comptence-Based Curriculum. Curriculum Framework PrePrimary to Upper Secondary. [s. l]: [s. n.], 2015. Available at: $\mathrm{http} / /$ reb.rw/fileadmin/competence_based_curriculum/syllabi/curriculum_framework_final_printed.co 
mpressed.pdf. Access in: 1. Aug. 2019.

SANCHAL, A.; SASHI, S. Students' attitudes towards learning mathematics: impact of teaching in a sporting context. Teachers and Curriculum, Hamilton, New Zealand, v. 17, n. 1, p. 89-99, 2017.

SCHOENFELD, A. H. Explorations of Students' Mathematical Beliefs and Behavior. Journal for Research in Mathematics Education, Reston, VA, v. 20, n. 4, p. 338-355, 1989.

SCHWEINLE, A.; MEYER, D. K.; TURNER, J. C. Striking the right balance: Students' motivation and affect in elementary mathematics. The Journal of Educational Research, London, v. 99, n. 5, p. 271-294, 2006.

SIEW, N. M.; LEE, B. N. Students' Algebraic Thinking and Attitudes towards Algebra: The Effects of Game-Based Learning using Dragonbox $12+$ App. The Research Journal of Mathematics and Technology, Beijing, v. 5, n. 1, p. 66-79, 2012.

STIGLER, J. W.; HIEBERT, J. Improving Mathematics Teaching The 1999 TIMSS Video Study. Improving Achievement in Math and Science, North Beauregard St. Alexandria, VA, v. 61, n. 5, p. 12-17, 2004.

STONE, J. R.; ALFELD, C.; PEARSON, A. D. Rigor and Relevance: Enhancing High School Students' Math Skills Through Career and Technical Education. American Educational Research Journal, Thousand Oaks, USA, v. 45, n. 3, p. 767-795, 2008.

SWAN, P. I hate Mathematics. 2004. Available at:

http://www.mav.vic.edu.au/files/conferences/2004/Swan.pdf. Access in: 4. Jul. 2019.

TUCK-CHOY, C.; TREAGUST, D. Students' Difficulties, Conceptions, and Attitudes Towards Learning Algebra: An Intervention Study to Improve Teaching and Learning Tuck-Choy Francis Chow. Perth Western Australia: Curtin University, 2011.

UKOBIZABA, F.; NDIHOKUBWAYO, K.; MUKUKA, A.; UWAMAHORO, J. Insights of teachers and students on mathematics teaching and learning in selected Rwandan secondary schools. African Journal of Educational Studies in Mathematics and Sciences, Accra, v. 15, n. 2, p. 93-107, 2019.

UKOBIZABA, F.; NDIHOKUBWAYO, K.; UWORWABAYEHO, A. Teachers' Behaviours Towards Vital Interactions that Attract Students' Interest to Learn Mathematics and Career Development.

African Journal of Educational Studies in Mathematics and Sciences, Accra, v. 16, n. 1, p. 85-94, 2020 .

UMUGIRANEZA, O.; BANSILAL, S.; NORTH, D. Exploring Teachers' Descriptions of Ways of Working with the Curriculum' in Teaching Mathematics and Statistics. African Journal of Research in Mathematics, Science and Technology Education, Abingdon, England v. 22, n. 1, p. 70-80, 2018.

YILMAZ, K. The Cognitive Perspective on Learning : Its Theoretical Underpinnings and Implications for Classroom Practices. The Clearing House: A Journal of Educational Strategies, Issues and Ideas, Abingdon, Englandv. 84, p. 204-212, 2011.

ZAHARA, A.; HOSSAIN, A. M. A comparison of cooperative learning and conventional teaching on student's achievement in secondary mathematics. Procedia - Social and Behavioral Sciences, Amsterdam, v. 9, p. 53-62, 2010. Available at:http://dx.doi.org/10.1016/j.sbspro.2010.12.115. Access in: 1. Aug. 2019. 